\title{
Experience Type Teaching Theory In Higher Vocational Teaching Of Applied Research
}

\author{
Zhiqiang Feng \\ Henan industrial trade vocational college, ZhengZhou, 450012, China \\ fzq2007@yahoo.cn
}

\begin{abstract}
Higher vocational education talent training goal is different from undergraduate education, higher vocational education pay more attention to emphasize its knowledge and skills, requires teachers to reflect on the traditional teaching method. Experience learning theory, put forward the complete model of learning: "experience learning circle", this paper puts forward some effective learning experience, this kind of method emphasizes the sharing and application, do the "learning by doing" experiential learning, learners to master the knowledge, give full play to the potential, is the effective method to improve the learning efficiency. Experiential learning has been widely used for the enterprise training to employees, is a popular way to training. This paper studies the experience type education teaching method of the theory and technology for higher vocational education teaching is of great significance.

Index Terms - Experience type teaching method, Higher vocational college teaching, Traditional teaching education information means
\end{abstract}

\section{Introduction}

Experience type Teaching (Experience Teaching) means in the Teaching process, according to the students' cognitive characteristics and rules, through the creation of the actual or repeated Experience situation and opportunity, present or representation, reducing the Teaching content, so that students in the process of close to understand and construct knowledge, development ability, to have an emotional, and the formation of the meaning of the Teaching and the Teaching form. Compared with the traditional teaching mode, experience type teaching that students pay attention to is an active participant, not a passive bystander and receiver; Emphasis on pay attention to study the subject of digestion and experience to share to sum up experience to solve practical problems as the guidance, Emphasis on learning to pay attention to the idea, thinking and attitude improvement; Focus on specific learning situation through the experience to learn. So through the use of scientific "multiple sensory learning method", namely, including case discussion, scene simulation, role playing, etc, make the education object through the experience gained his experience, thus in the limited time available to obtain the biggest harvest.

\section{Helpful Hints}

\section{A. Technical Process}

Coaching experience type learning to pay attention to in the study, to achieve the effect of unifying the experience type is to make your own, and to swim in the swimming coach and constant communication with companions, summarized, groping his blind spots and can swim fastest posture, pool coach is just a mirror, for your performance continuously make feedback and encourage.

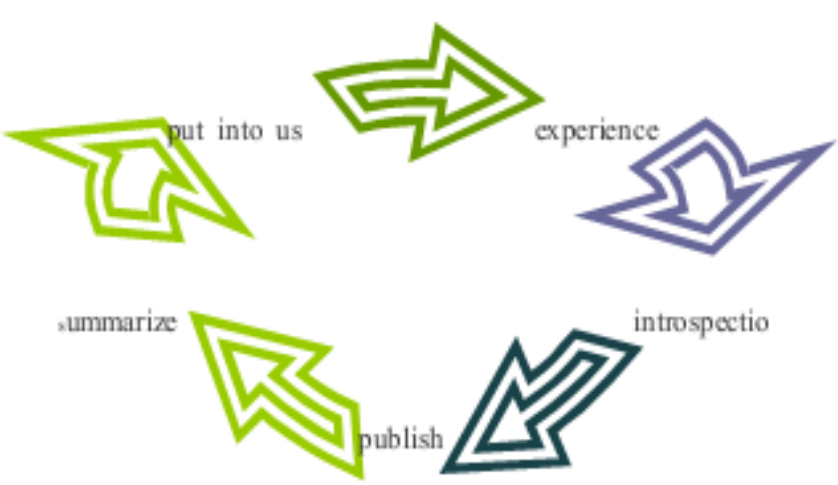

Fig. 1 Experiential circle learning theory

1) Practice Experience Is Given Priority To: It with practice experience is given priority to, for some hobby practice students, it is very glad to accept way, student's interest to participate will be improved obviously.

2) Take The Student As The Center: Experiential education emphasizes the subjective initiative to learn, so that the students become the center of teaching, teachers should give students free activities and show yourself the chance of them making in active practice, think positive exploration state, let them active brains, saying, to begin, independent observation, comparison, lenovo and induction. In practice, to feel, to discover, to evaluation, so as to constantly construct their own knowledge, and gradually developed experience learning ability.

3) The Combination Of Experience And Reflection: The experience type teaching experience and reflection is a combination of, in line with the formation of the students' knowledge rules, different from some rote and 
TABLE I Experience Type Teaching And Traditional Teaching Difference

\begin{tabular}{|l|l|l|}
\hline Basic Element & traditional teaching & experiential teaching \\
\hline Learning Subject & personal & Group and individual \\
\hline Learning Model & Individual learning & $\begin{array}{l}\text { Between students and } \\
\text { learn from each other }\end{array}$ \\
\hline Learner Role & $\begin{array}{l}\text { Passive acceptance, one- } \\
\text { way reception }\end{array}$ & $\begin{array}{l}\text { Participate, summarize } \\
\text { feedback }\end{array}$ \\
\hline Teacher Role & Who taught & coadjutant \\
\hline Teachers' Duty & $\begin{array}{l}\text { One-way communication, } \\
\text { mainly teaching }\end{array}$ & $\begin{array}{l}\text { To provide a experience } \\
\text { learning environment }\end{array}$ \\
\hline $\begin{array}{l}\text { Learning } \\
\text { Environment }\end{array}$ & Restrictive, boring & Easy, agile \\
\hline Feedback Key & $\begin{array}{l}\text { Pay attention to the } \\
\text { experimental results and } \\
\text { test scores }\end{array}$ & $\begin{array}{l}\text { Pay attention to the } \\
\text { process and review }\end{array}$ \\
\hline $\begin{array}{l}\text { Teaching } \\
\text { Method }\end{array}$ & PowerPoint & $\begin{array}{l}\text { MindManager and } \\
\text { PowerPoint }\end{array}$ \\
\hline Teaching Link & Course process single \\
\hline Process & $\begin{array}{l}\text { Course process } \\
\text { comprehensive }\end{array}$ \\
\hline obvious & $\begin{array}{l}\text { Teachers and students } \\
\text { strong interactivity }\end{array}$ \\
\hline
\end{tabular}

\section{B. Experience Type Teaching And Traditional Teaching} Means Difference

1) Teaching Means:Experiential learning process has two basic structure dimension, the first called digestion dimensions, including two opposite to the mode of experience: one is through the direct understanding specific experience. The second is through the indirect understanding symbol for experience. The second is called transformation dimension, including two opposing experience transformation modes: one is through the internal reflections; The second is through the external action. In the learning process both be short of one cannot. Experience learning process is constant experience digestion and the modification process.

2) Learning Circle:Because everyone's inner personality, temperament differences, as well as the life, work experience and education background of "diversity", leading to each student's learning style is not the same. According to the study theory of circle, learners' learning style roughly divided into four categories: experience learner, reflection type learners, theoretical type learners and applied learners. Cooper think, these four types of learning style does not exist, the value of quality discrimination between them have certain complementarity.
TABLE II Teaching information means PowerPoint and MindManager the relationship and difference

\begin{tabular}{|c|c|c|c|c|}
\hline $\begin{array}{l}\text { Basic } \\
\text { Function }\end{array}$ & $\begin{array}{l}\text { Basic } \\
\text { Advantage }\end{array}$ & Powerpoint & Mindmanager & $\begin{array}{l}\text { Teaching } \\
\text { Process }\end{array}$ \\
\hline $\begin{array}{l}\text { More multi- } \\
\text { media } \\
\text { contents }\end{array}$ & $\begin{array}{l}\text { Expressive } \\
\text { force strong }\end{array}$ & Language & linear & $\begin{array}{l}\text { Move the } \\
\text { brain, } \\
\text { mouth, } \\
\text { hand }\end{array}$ \\
\hline $\begin{array}{l}\text { information } \\
\text { presentation }\end{array}$ & Quick and easy & characters & Quantity & watch \\
\hline $\begin{array}{l}\text { information } \\
\text { preservation }\end{array}$ & recycle & picture & reason & compare \\
\hline $\begin{array}{l}\text { Information } \\
\text { copy }\end{array}$ & $\begin{array}{l}\text { Easy } \\
\text { communication }\end{array}$ & table & logicality & associate \\
\hline $\begin{array}{l}\text { information } \\
\text { processing }\end{array}$ & $\begin{array}{l}\text { Make } \\
\text { convenient }\end{array}$ & animation & $\begin{array}{l}\text { intuitive } \\
\text { insight }\end{array}$ & conclude \\
\hline $\begin{array}{l}\text { information } \\
\text { conversion }\end{array}$ & $\begin{array}{l}\text { The use of } \\
\text { concise }\end{array}$ & music & globality & feel \\
\hline $\begin{array}{l}\text { Making } \\
\text { simple }\end{array}$ & $\begin{array}{l}\text { Way } \\
\text { conversion }\end{array}$ & $\begin{array}{l}\text { film and } \\
\text { television }\end{array}$ & similarity & find \\
\hline widely use & $\begin{array}{l}\text { Vector } \\
\text { amplification }\end{array}$ & pronunciation & $\begin{array}{l}\text { Nonverbal } \\
\text { ability }\end{array}$ & evaluate \\
\hline
\end{tabular}

\section{Techniques and methods}

\section{A. Role Playing}

Most of the higher vocational students are not professional experience, many course principle and thought, for them every farther. How to make them from the passive "role-playing" this game activities, to build a practical work and actual position scene, let the students in this situation and learning content in the union of produce association and emotional resonance. Through the course of the design process strictly, the process of various teaching activities of the role of the design, the role of distribution, to discuss the designing, lines to a series of planning, and then after the stage game and performance. Actor is not based on objective, the outsider's position, but as a subjective, the role of the consideration question, be personally on the scene to realize them to consider the actual position of role and the way.

So can make students from the role, simulation situation to experience subject role behavior characteristics principle and method. The teacher is in one side of the inspiration and guidance and comment on and recreation, can achieve very good effect.

\section{B. Case Discussion}

Case teaching is discussed in the students master the basic knowledge on the basis of on the teacher's careful planning and guidance, let the students' comprehensive use of the classes of the real position working for specific analysis, improve its found the problem, and the ability to analyze and solve problems, and at the same time, develop good communication skills and team spirit way of teaching. 
In case discussion, the students to learn the form of group is a case to discuss, organization and share. Since each student's experience is different, perspective has different, so to understand things can't completely the same, this will cause student exchange. Students communicate with each other, discussion, different opinions in the dispute, to understand the content of the learning experience knowledge. Higher vocational courses, many teaching contents mostly can use case to discuss ways to teaching, relative to the boring theory teaching, case teaching can increase the classroom teaching more interesting, effective arouses student's study enthusiasm, it is to point to make a commitment to learning in alive.

\section{The Classroom Communication}

Psychology master gaza mention and summarizes the five kinds of human communication mode: please, accused, super reason, broke and real consistent responses. In the crowd, 50\% is please type; $30 \%$ of the people are accused type; $15 \%$ of the people are super cerebral; $0.5 \%$ of the people are interrupted me and type, the four communication model accounted for $95.5 \%$, only $4.5 \%$ of the people are the real consistent type. To success is true consistency of communication, in the real consistency communication, communicator according to their own needs and aspirations, and not to respond to just get out of a difficulty, can free use of wisdom, and no damage to the emotion and spirit, it needs mutual communication real respect and acceptance. Consistency means of communication is not only the correct behavior, but behind the behavior, reaching to the spiritual world of the journey, heart and soul of the bridge between. Method, we should respect everyone's uniqueness, be sure the value of yourself, know how to appreciate, and accept others, can truly feel the integrity of the self, to create and beautiful!

\section{External Training}

Use of various social resources for students contact out practice enterprise unit; invite industry senior people and students held a forum; organizes the student to participate in the social various business fair and commodity fair; students are encouraged to does not affect the learning situation of short time field activities. Through the use of various resources to let the students learn to communicate with others, to improve the social adaptation ability.

\section{Some Common Mistakes}

\section{A. Application Methods.}

In the course of teaching design teaching situation to let the students in practice, inspection plan, assumptions, and its correctness and rationality of the judge. Situation can be to solve the problem, also can full series of task, but whether problem or task, are real, meaningful. Each task according to the information plan check the implementation of the decision evaluation complete "action" process.

\section{B. Experience Type Teaching Is A Complete Process Of Teaching Activities.}

The active participation experience, true feelings, really experience, through the experience type teaching activities fully mobilize students' learning enthusiasm and initiative, lead the students sense of scene, realize emotion, understand teachers' teaching content.

\section{Acknowledgment}

The author in the research and writing this thesis process, I read some experiential education teaching aspects of the works and papers, upon completion of this study, thank the authors. In the study of this subject in the process, many times I am a practical theory and the application of the proposed method.

\section{References}

[1] The Research Experience Type Innovation Teaching Implementation Of The New Curriculum - The New Idea And New Technology. WenHengFu. Heilongjiang People's Press, 2010.10

[2] The Experience Type Business English. ChenMingYao. Defense Industry Press, 2007.12

[3] The Experience Type Teaching Method In The Application Of Computerized Accounting Professional Course Learning. MaLiMei, LiuFengWen. The Accounting Online, 2010.9

[4] The Higher Vocational Marketing Experience Type Teaching Method To Explore. ZhangXiaoLian. Beijing Electric Power College Journal: Social Science Edition,2010 B08 period

[5] The Marketing Course Experience Type Teaching Method And Practice. LuoXinQing .The Education Teaching Bbs, 2010, 29 period

[6] How To Through The Experience Type Teaching Improve Class Effect. GongYanFu .Little Wisdom Report (WenZong), 2011. 13

[7] The Experiential Training - Universities Employment Instruction Of The New Way. LiuJianXin. YuXinLi .Chinese college students employment 2004,24 period

[8] EDUCATION. WangHanLan,WangDaoJun. Beijing People's Education Press, 2003.6 